\title{
Artikel
}

\section{De kleur van de Omgevingswet}

\author{
Prof. dr. Ch.W. (Chris) Backes*
}

\section{Kleur van het omgevingsrecht in 2001}

Op 23 maart 2001 heeft Lex Michiels zijn inaugurele rede als nieuwe hoogleraar bestuursrecht, in het bijzonder omgevingsrecht, aan de Universiteit Utrecht uitgesproken. De titel was 'Kleur in het omgevingsrecht'. ${ }^{1}$ Daarin ging het met name, wat verkort gezegd, om de overwinning van de schotten tussen het ruimtelijkeordeningsrecht en het milieurecht en de mogelijkheden en beperkingen van verschillende onderdelen van het omgevingsrecht. Volgens Michiels leidt koste wat kost integreren van de verschillende onderdelen van het omgevingsrecht niet tot de meest wenselijke en voor de omgeving beste oplossing. Volstaat men met het zonder differentiatie mengen van alle kleuren van het omgevingsrecht, dan is het resultaat een onbestemde bruingrijze massa. 'Maar mengen op zichzelf is ook niet per se de hoogste schilderswijsheid', aldus Michiels. Integreren is volgens hem alleen aangewezen waar dat een aantoonbare 'meerwaarde heeft en ook uitvoerbaar is'. In de andere gevallen moeten de aparte kleuren onvermengd blijven bestaan en moet er worden afgestemd, aldus de orator. $^{2}$ Een mooi schilderij ontstaat immers, zo zou ik willen toevoegen, slechts als krachtige basiskleuren onvermengd worden gebruikt waar dat past en overal mengen in verschillende combinaties waar dat nodig en mogelijk is om een deel van het schilderij optimaal in te

* Prof. dr. Ch.W. Backes is hoogleraar Omgevingsrecht en verbonden aan het Utrecht Centre for Water, Oceans and Sustainability Law (UCWOSL).

1. F.C.M.A. Michiels, Kleur in het omgevingsrecht (oratie Utrecht), Den Haag: Boom Juridische uitgevers 2011.

2. Michiels 2011, p. 57. vullen. Dat alles lijken - wie had anders gedacht van de orator? - wijze adviezen. Het loont dus om de oratie van Michiels nog eens ter hand te nemen. Dan komt men overigens ook enkele voorbeelden tegen over de ontwikkeling die het omgevingsrecht in de afgelopen zestien jaar heeft ondergaan. Zo merkt Michiels bijvoorbeeld op dat 'tamelijk nieuw in het omgevingsrecht is dat de elementen van water en natuurbescherming een prominente rol spelen'. Dat water en natuur niet altijd al een belangrijke rol in het omgevingsrecht spelen, is vanuit huidig perspectief wellicht een verrassing, maar zeker waar. Het waterrecht was nog in de jaren negentig van de afgelopen eeuw met name waterstaatsrecht en met het natuurbeschermingsrecht hield zich nauwelijks iemand bezig. In deze korte bijdrage wil ik echter niet ingaan op de emancipatie van bepaalde deeldisciplines van het omgevingsrecht, maar bekijken wat de wetgever met de schilderwijsheden van Michiels heeft gedaan. Eén ding is zeker: in de afgelopen twee decennia heeft het omgevingsrecht een enorme ontwikkeling doorgemaakt. Men zou zelfs kunnen beweren dat deze twee decennia, gerekend vanaf de laatste jaren van het afgelopen millennium tot aan de (verwachte) inwerkingtreding van de Omgevingswet $(\mathrm{Ow})$ in 2019, een soort ontstaansfase van het (integrale) omgevingsrecht zijn geweest. Toen ik in 1998 mocht meewerken aan de oprichting van het Centrum voor Omgevingsrecht en -beleid kreeg ik van velen te horen dat het woord 'omgevingsrecht' het niet zou halen omdat het een germanisme is. Hoewel 'omgevingsrecht' pas in 2016 in de Van Dale is opgenomen en daarbij de kanttekening 'voorlopig opgenomen' is geplaatst, lijkt het begrip nog geen tien jaar na 1998, en zeker nu, helemaal ingeburgerd, althans in de vakwereld. Belangrijke mijlpalen op weg daarnaartoe zijn geweest, naast de oprichting van het, inmiddels tot Centre for Water, Oceans and Sustainability Law omgevormde, Centrum voor Omgevingsrecht en -beleid, het eerste nummer van het Tijdschrift voor 
Omgevingsrecht in april $2005,{ }^{3}$ de eerste druk van het boek Omgevingsrecht in $2006^{4}$ en de, als ik het goed zie, eerste 'erkenning' van het begrip 'omgevingsrecht' door de wetgever in het wetsvoorstel voor de Wabo in $2006 .{ }^{5}$ Deze eerste fase van het omgevingsrecht komt met de verwachte inwerkingtreding van de Ow in 2019 tot een zeker einde. Meer dan op de vraag of het omgevingsrecht daarmee volwassen is geworden of pas zijn kinderdagen heeft voltooid, wil ik mij hier richten op de kleur van het magnus opus van de wetgever op dit terrein, de Ow. Dat moet immers, als het aan de wetgever ligt, een robuust en bestendig wettelijk kader vormen dat de toekomst van het omgevingsrecht in sterke mate bepaalt, althans wat de regelgeving betreft.

\section{Een kleurloze Omgevingswet?}

Welke kleur heeft de Ow dan gekregen? Is het een grijsbruin mengsel geworden waarin de aparte delen van het omgevingsrecht niet meer herkenbaar zijn? Bestaat er straks nog iets als milieurecht of natuurbeschermingsrecht, of zijn niet alleen die begrippen, maar ook die beleidskaders binnenkort achterhaald en verdwenen ten gunste van een inhoudelijk vaag omgevingsrecht en -beleid? Of rijst, als wij naar de Ow kijken, het beeld van een bont schilderij met een kleurrijke regenboog en allerlei schakeringen van blauw, groen, rood, grijs en vele andere mengkleuren die passen bij verschillende onderdelen van het tableau?

\subsection{Doelstelling}

Art. $1.3 \mathrm{Ow}^{6}$ geeft de doelstelling van de $\mathrm{Ow}$ als volgt weer:

'Deze wet is, met het oog op duurzame ontwikkeling, de bewoonbaarheid van het land en de bescherming en verbetering van het leefmilieu gericht op het in onderlinge samenhang

a. bereiken en in stand houden van een veilige en gezonde fysieke leefomgeving en een goede omgevingskwaliteit, ook vanwege de intrinsieke waarde van de natuur, en

4. Thans M.N. Boeve \& F. Groothuijse, Omgevingsrecht (vijfde druk), Groningen: Europa Law Publishing 2016.

5. Regels inzake een vergunningstelsel met betrekking tot activiteiten die van invloed zijn op de fysieke leefomgeving en inzake handhaving van regelingen op het gebied van de fysieke leefomgeving (Wet algemene bepalingen omgevingsrecht), Kamerstukken II 2006/07, nr. 30 844, nr. 3, i.h.b. p. 12, waar de omslag van het begrip 'de VROM-vergunning' naar het begrip 'de omgevingsvergunning' wordt toegelicht.

6. Tenzij anders aangegeven, ben ik voor deze bijdrage uitgegaan van de Ow zoals die zal komen te luiden als de in de periode tot het voorjaar 2017 gepubliceerde voorstellen tot wijziging van de Ow door de Invoeringswet Omgevingswet en de aanvullingswetten in de thans voorgestelde vorm kracht van wet zouden krijgen. Dat heeft uiteraard als nadeel dat het om een nog niet vaststaande wettekst gaat die het parlementaire proces nog moet doorlopen. b. doelmatig beheren, gebruiken en ontwikkelen van de fysieke leefomgeving ter vervulling van maatschappelijke behoeften.'

Dit lijkt meer kleur te geven dan de wetten die in de Ow opgaan. Zo kennen, respectievelijk kenden de Wet milieubeheer (Wmb), de Wet ruimtelijke ordening (Wro) en de Natuurbeschermingswet 1998 (Nbw 1998) geen bepaling die de doelstelling van deze wetten expliciteert. Alleen de nieuwe Wet natuurbescherming (art. 1.10 Wnb) en de tamelijk recente Waterwet (art. $2.1 \mathrm{Wtw}$ ) geven aan waarop deze wetten zijn gericht. Is deze nieuwe tendens om de doelstelling van een wet in de wettekst zelf te expliciteren een nieuwe trend? Is het een mode of een weldoordachte ontwikkeling? Of zijn er redenen waarom bijvoorbeeld de $\mathrm{Wmb}$ geen dergelijke doelstelling kent, maar de Ow wel? Deels zal dit zeker met tradities en stijlen van wetgevingstechniek te maken hebben. Deels echter lijkt er bij de Ow ook bijzondere aanleiding te bestaan om de doelstellingen van de wet nader te beschrijven. Wetten als de Nbw 1998 of de Wmb spreken in dit opzicht voor zich. Ook zonder een expliciet artikel lijkt het duidelijk dat de doelstellingen het beschermen en ontwikkelen van de natuur respectievelijk de bescherming van het milieu zijn. Bij de $\mathrm{Ow}$ is door de integratie van alle beleidsterreinen van het omgevingsrecht wat minder vanzelfsprekend wat deze wet beoogt. Of, anders gezegd: bruingrijs is een minder duidelijke kleur dan bijvoorbeeld groen of blauw.

De explicitering van haar doelstelling in art. $1.3 \mathrm{Ow}$ zou men dus kunnen zien als kleur bekennen. Maar wat voor een kleur is dat dan? Wat betekent art. 1.3 Ow? Enerzijds zijn de pretenties van dit artikel, gelooft men de toelichting op het wetsvoorstel, hoog:

'De in deze bepaling neergelegde maatschappelijke doelen geven richting aan de uitvoering en toepassing van de Omgevingswet. Dit geldt zowel voor bedrijven en burgers (denk aan de zorgplicht van artikel 1.6) als voor bestuursorganen. ${ }^{7}$

Dat wordt echter snel gerelativeerd:

'Doel a staat niet in de weg aan activiteiten die vooral doel $b$ dienen, zoals de ontwikkeling van een weg ter vervulling van de maatschappelijke functie "mobiliteit". Doel b staat niet in de weg aan overheidsmaatregelen die vooral doel a dienen, zoals het vaststellen van algemene regels over activiteiten die het milieu belasten. Toepassing van de wet vereist het zoeken naar oplossingen die zoveel mogelijk tegemoet komen aan beide doelen en de belangen daarachter. En waar dat niet kan, het maken van een belangenafweging. ${ }^{8}$

Veel richting geeft dat niet. Op de wet gebaseerde beleidskeuzen en besluiten kunnen evengoed zijn gericht op de bescherming en ontwikkeling van de 'omgevingskwaliteit' (sub a) als op het gebruiken van de 
omgeving ten behoeve van welke maatschappelijke behoeften dan ook (sub b). Art. 1.3 Ow houdt meerdere richtingwijzers in, die in de volstrekt tegengestelde richting kunnen wijzen. Wat overblijft is uiteindelijk de opdracht om goede afwegingen te maken die alle betrokken belangen omvatten en de soms tegenstrijdige subdoelstellingen zo veel mogelijk faciliteren. Een duidelijke richting of kleur laat zich hier nu juist niet uit afleiden.

De vraag is of de aanhef van art. $1.3 \mathrm{Ow}$ hier nog iets aan toevoegt en een zekere beperking van de afwegingsruimte bevat. De wettekst lijkt dat te suggereren omdat alle afwegingen uiteindelijk in dienst moeten staan van een groter doel, namelijk duurzame ontwikkeling, de bewoonbaarheid van het land en de bescherming en verbetering van het leefmilieu. Het begrip duurzame ontwikkeling wordt 'gelet op de centrale plaats die dit begrip binnen de wet inneemt' in de bijlage bij art. 1.1 Ow nader gedefinieerd. Volgens deze definitie is duurzame ontwikkeling 'een ontwikkeling die voorziet in de behoeften van de huidige generatie zonder de mogelijkheden voor toekomstige generaties om in hun eigen behoeften te voorzien in gevaar te brengen'. ${ }^{9}$ Als men dat serieus neemt, dan zou daardoor de afwegingsruimte waarin de $\mathrm{Ow}$ voorziet ten minste tot op zekere hoogte worden beperkt. Thans zijn onze economie en levenswijze immers alles anders dan duurzaam. De ecologische voetafdruk in Nederland was in 2013 met een factor 5,8 te groot: ons verbruik per persoon van biocapaciteit is 5,8 maal zo groot als de biocapaciteit die wij produceren. ${ }^{10}$ Het is makkelijk voorzienbaar dat al enkele generaties na 'ons' de wereld niet meer kan voorzien in de behoeften aan energie en grondstoffen, ten minste als wij met onze manier van leven doorgaan zoals wij dat thans doen en als de overige wereldbevolking zich daaraan zou aanpassen. ${ }^{11}$ Moet dus bijvoorbeeld de omgevingsvisie van het Rijk (zie art. 3.1 lid $3 \mathrm{Ow}$ ) aangeven hoe in de komende jaren en decennia wordt toegewerkt naar een duurzame Nederlandse economie, die de ecologische voetafdruk terugbrengt naar verantwoorde proporties en het bestaande gevaar dat toekomstige generaties niet meer in hun behoeften kunnen voorzien ten minste iets vermindert? Met het oog op de aanhef van art. $1.3 \mathrm{Ow}$ zou dat een logische eis zijn. Ingevolge art. $3.2 \mathrm{Ow}$ dienen omgevingsvisies te bevatten:

a. een beschrijving van de hoofdlijnen van de kwaliteit van de bestaande leefomgeving;

b. de hoofdlijnen van de voorgenomen ontwikkeling, het gebruik, het beheer, de bescherming en het behoud van het grondgebied;

9. Zie in dit verband ook S. van 't Foort \& J. Kevelam, Het waarborgen van duurzaamheid in de Omgevingswet, TO 2015, afl. 1, p. 8 e.v.

10. Global Footprint Network 2016. National Footprint Accounts, 2016 Edition, world graphs; data.footprintnetwork.org/countryTrends.html? $\mathrm{cn}=150$ \& type $=\mathrm{cdPC}$.

11. Zie W. Steffen e.a., Planetary boundaries: Guiding human development on a changing planet, Science 2015, DOI: 10.1126/science.1259855; zie ook Ch.W. Backes, Law for a circular economy, Den Haag: Eleven International Publishing 2017, p. 7 e.v. c. de hoofdzaken van het voor de fysieke leefomgeving te voeren integrale beleid.

Dat is volkomen inhouds- en kleurloos. Staat art. 3.2 Ow dus op gespannen voet met art. 1.3 Ow? Ik denk het niet. Art. $1.3 \mathrm{Ow}$ is nu juist bedoeld om de uitoefening van de op zich neutraal en kleurloos omschreven bevoegdheid van art. 3.2 Ow met inhoud te vullen en tot op zekere hoogte te sturen. Daarom lijkt het mij noodzakelijk dat bijvoorbeeld uit de omgevingsvisie van het Rijk duidelijk wordt wat thans ons verbruik aan energie en grondstoffen is, in hoeverre dit duurzaam is en of, en zo ja hoe, op de middellange en lange termijn naar een duurzame ontwikkeling zal worden toegewerkt. Art. 1.3 Ow stuurt de inhoud van een omgevingsvisie dus niet direct en is, gezien de veelheid en verscheidenheid van de in dit artikel als gelijkwaardig opgesomde subdoelen, ook niet in grote mate beperkend voor de afwegingen die bij de toepassing van de verschillende bevoegdheden uit de wet zullen worden gemaakt. Art. $1.3 \mathrm{Ow}$ is echter niet geheel kleurloos. Beslissingen en beleid die ertoe leiden dat toekomstige generaties niet meer in hun behoefte kunnen voorzien of (delen van) het land onbewoonbaar wordt (worden), lijken niet in overeenstemming met de $\mathrm{Ow}$ te zijn. Of, anders gezegd, de Ow wil voorkomen dat het omgevingstafereel overwegend donkerbruin tot zwart wordt. Dat klinkt wellicht vanzelfsprekend, maar lijkt meer consequenties te kunnen hebben dan wellicht verwacht. Een weinig voortvarend klimaatbeleid of het niet effectief bestrijden van de aardbevingen als gevolg van de onttrekking van aardgas zal door art. $1.3 \mathrm{Ow}$ onder nog grotere motiverings- en rechtvaardigingsdruk komen. Ook zal art. $1.3 \mathrm{Ow}$ bijvoorbeeld ertoe noodzaken dat er een duidelijke oplossingsstrategie komt voor de problematiek van inklinking en daardoor veroorzaakte verzilting in sommige delen van Nederland.

Al met al lijkt art. 1.3 Ow dus te voorzien in een palet van verschillende kleuren die kunnen worden gebruikt om het omgevingsschilderij 'Mooi Nederland' te maken. Daarenboven lijkt deze bepaling echter ook een zekere sturende werking op de kleurstelling van dit schilderij te impliceren.

\subsection{Instrumenten}

De kleurloosheid van het instrument omgevingsvisie werd zojuist al aangeduid. Ook de andere hoofdinstrumenten, het programma, het omgevingsplan en omgevingsverordeningen, vergunningen, projectbesluiten en algemene regels hebben in beginsel geen kleur. Het zijn instrumenten die voor allerlei doelen binnen de hoofddoelstellingen uit art. 1.3 Ow kunnen worden ingezet en waarmee die doelstellingen kunnen worden bereikt. Het zijn penselen, kwasten en pennen van verschillende pluimage, waarmee dikke grote lijnen en vage aanduidingen op het doek kunnen worden gebracht of juist heel specifieke, precieze tekeningen kunnen worden gemaakt. Dit instrumentele karakter benadrukt het belang van de inhoudelijk enigszins sturende norm van art $1.3 \mathrm{Ow}$, maar demonstreert ook dat de Ow op zich 
weinig kleur heeft. Of Nederland zijn klimaatdoelen haalt, of Nederland kiest voor een enorme uitbreiding van snelwegen om het individueel autoverkeer te faciliteren en of de biodiversiteit verder achteruitgaat: dat alles wordt door de vormgeving van de (hoofd)instrumenten in de Ow niet bepaald. Hetzelfde geldt voor de vraag of het omgevingsschilderij van Nederland er overal redelijk vergelijkbaar uitziet of een grote variatie laat zien met krachtige kleuren op verschillende plekken.

Er zijn echter uitzonderingen op deze 'kleurneutraliteit'. Zo bepaalt art. $2.13 \mathrm{Ow}$ dat met het oog op het waarborgen van de veiligheid en het voorkomen of beperken van wateroverlast in de provinciale omgevingsverordening omgevingswaarden moeten worden vastgesteld voor de veiligheid van bij de verordening angewezen andere dan primaire waterkeringen, voor zover die niet bij het Rijk in beheer zijn, en ook voor gemiddelde overstromingskansen in bepaalde gebieden met het oog op de bergings- en afvoercapaciteit. Ook de ingevolge art. 2.15 lid 1 sub d en e OW verplicht door het Rijk vast te stellen omgevingswaarden betreffen de veiligheid van waterkeringen. Dat zijn dan ook de enige onderwerpen waarvoor een verplichting tot vaststelling van omgevingswaarden niet uit het EU-recht voortvloeit (zoals het geval bij de omgevingswaarden voor luchtkwaliteit of de kwaliteit van oppervlaktewateren), maar waarvoor de nationale wetgever, in navolging van de thans geldende Wtw, voor een verplichting tot vaststelling van omgevingswaarden kiest. Dat is dus een duidelijke blauwe penseelstreek op het voor het overige alleen zeer gedeeltelijk op grond van Europese verplichtingen ingekleurd doek.

Ook al bepaalt de vormgeving van de instrumenten in de Ow de kleur van het omgevingsschilderij maar in zeer beperkte mate, één ding lijkt toch wel duidelijk te zijn. Het schilderij zal straks bonter en meer geschakeerd worden dan thans het geval. Dat is althans de bedoeling. Dat de Ow het voornemen tot decentralisatie van taken en bevoegdheden serieus neemt, komt op velerlei wijze tot uitdrukking, bijvoorbeeld in de toewijzing van taken (art. 2.16 e.v. Ow), in het afzien van normstelling op rijksniveau en in de verruimde mogelijkheden om van algemene normen lokaal af te wijken. In het bijzonder de thans nog in rijksregels (bijvoorbeeld het Activiteitenbesluit milieubeheer) opgenomen regels over lokale hinder van geluid, trilling en geur, maar ook over externe veiligheid zullen in belangrijke mate straks ter dispositie van gemeenten staan. Zij kunnen dat in het omgevingsplan regelen en daarbij 'aansluiten bij de plaatselijke situatie'. Dat houdt dus in dat in de ene gemeente grijs extra wordt benadrukt, in de andere blauw en in de derde groen. Het kan ook betekenen dat het doek juist wit blijft, er wordt afgezien van regelgeving. Hetzelfde geldt voor het al dan niet vergunningplichtig maken van bouwactiviteiten en het al dan niet reguleren van bepaalde lozingsactiviteiten in regionale wateren.

Bij de toewijzing van taken bevat de Ow overigens weinig nieuws. De decentralisatieslagen zijn hier eerder gemaakt, door middel van andere wetten of wetsvoor- stellen (bijvoorbeeld Wet afschaffing plusregio's ${ }^{12}$ ) en vooral bestuursakkoorden (bijvoorbeeld bestuursakkoorden water en natuur). Of de metamorfose van het bestemmingsplan naar het omgevingsplan met ruime mogelijkheden tot differentiatie in de regulering en sturing van locatierelevante activiteiten zal bijdragen tot een bonter, minder gelijkmatig beeld en versterking van de mogelijkheden om lokaal op bepaalde plekken bepaalde kleuren of kleurcombinaties de nadruk te geven, is nog afwachten. Het feit dat een omgevingsplan, anders dan een bestemmingsplan, omgevingswaarden en programma's kan bevatten en bovendien maatwerkregels, maatwerkvoorschriften en gelijkwaardigheidsbepalingen maakt duidelijk dat meer flexibiliteit en verscheidenheid bedoeld is. ${ }^{13}$ Het gaat dan vooral om flexibiliteit voor het gemeentebestuur om bij omgevingsplan van landelijk gestelde omgevingswaarden en materiële eisen af te wijken door het stellen van aanvullende eisen of het voorzien in uitzonderingen van landelijk gestelde eisen. In de literatuur is echter door verschillende auteurs de verwachting uitgesproken dat dit niet zo vaak en omvangrijk zal gebeuren en van de, theoretisch bestaande, mogelijkheden tot meer differentiatie nauwelijks gebruik zal worden gemaakt. ${ }^{14}$ Of het omgevingsschilderij van Nederland dus straks veel bonter wordt, moet nog blijken.

\subsection{Materiële normen, beginselen en afwijkingsmogelijkheden}

De Ow zelf bevat weinig materiële normen. De beoordelingskaders voor activiteiten zijn slechts voor een klein deel te vinden in de wet zelf. Hoofdstukken 4 en 5 Ow bevatten immers enkel de bevoegdheid en deels verplichting om regels vast te stellen en niet de algemene regels of maatstaven voor de individuele beschikkingen zelf. Soms echter komt een gedetailleerd geformuleerde verplichting tot het vaststellen van een algemene regel in een algemene maatregel van bestuur $(\mathrm{AMvB})$ feitelijk neer op materiële normstelling. Wellicht nog beter gezegd: de wettelijke bepaling bevat dan de inhoudelijke, normatieve keuzes voor de in de AMvB's op te nemen normstelling. Als voorbeeld moge hier worden verwezen naar art. 4.35 lid $2 \mathrm{Ow}$, dat luidt:

'2. De regels strekken er in ieder geval toe dat het vangen of doden vanuit een in Nederland geregistreerd vaartuig of het aan boord van een in Nederland geregistreerd vaartuig verwerken van walvissen is verboden.'

Inhoudelijk worden de normatieve keuzes dus in de wet gemaakt, de normstelling zelf vindt echter pas plaats in een AMvB. Dat is een mijns inziens onnodig omslachtige wetgevingstechniek. Voor het allergrootste deel ech-

12. Stb. 2014,557

13. Zie hierover bijv. N.S.J. Koeman, Het omgevingsplan in de nieuwe Omgevingswet, TO 2016, afl. 4, p. 97 e.v.

14. Zie bijv. o.a. J.R. van Angeren, Het omgevingsplan in de Omgevingswet, TO 2016, afl. $1 / 2$, p. 4 e.v. en A.G.A. Nijmeijer, Reactie op 'Het omgevingsplan in de Omgevingswet', TO 2016, afl. 3, p. 91 e.v. 
ter wordt de materiële normstelling zelf opgenomen in de AMvB's of zelfs in instructieregels die op grond van verschillende wettelijke bevoegdheden met name uit afdeling $2.5 \mathrm{Ow}$ moeten worden uitgevaardigd. Niet de formele wetgever, maar de regering maakt dus de inhoudelijke keuzes en bepaalt zo de kleur van het omgevingsschilderij. Op de vraag of het parlement als (mede)wetgever op deze wijze niet te zeer buiten spel wordt gezet, zal ik hierna nog terugkomen.

Die openheid en kleurloosheid van de Ow zelf door het uitsluitend regelen van bevoegdheden of de verplichting om materiële normen in gedelegeerde wetgeving te voorzien zouden tot op zekere hoogte kunnen worden gecompenseerd door het in de Ow opnemen van inhoudelijke beginselen, zoals milieubeginselen. Juist als de wetgever ervoor kiest om niet alleen te volstaan met weinig gedetailleerde normen, maar zelfs geheel geen normen in de formele wet op te nemen, ligt het voor de hand dat de (formele) wetgever iets aan inkleuring en inhoudelijke sturing meegeeft door de opname van (milieu)beginselen in de wet. Daar is in de literatuur voor gepleit en bij de totstandkoming van de $\mathrm{Ow}$ ook over gediscussieerd. ${ }^{15}$ De vrees was en is echter dat de opname van beginselen als instrument om de uitoefening van alle mogelijke instrumenten uit de wet in te kleuren zou leiden tot een toename aan beroepen en een juridisering van de beginselen. Daarom is gekozen voor een soort compromis. Ten eerste bepaalt art. 23.6 Ow dat in de nota van toelichting van de AMvB's ${ }^{16}$ moet worden gemotiveerd 'op welke wijze rekening is gehouden met het voorzorgsbeginsel, het beginsel van preventief handelen, het beginsel dat milieuaantastingen bij voorrang aan de bron dienen te worden bestreden en het beginsel dat de vervuiler betaalt'. Ten tweede schrijft art. $3.3 \mathrm{Ow}$ voor dat in een omgevingsvisie rekening wordt gehouden met de hiervoor genoemde beginselen. Dat zal dus ook uit (de motivering van) de omgevingsvisie moeten blijken. Hiermee is tot op zekere hoogte iets aan materiële inkleuring van de $\mathrm{Ow}$ en de daarop gebaseerde AMvB's verzekerd. De beide artikelen hebben echter niet tot gevolg dat uitvoeringsmaatregelen zoals vergunningen of algemene regels door algemene (milieu)beginselen worden beinvloed. Of dat een groot gemis is, weet ik niet. Belangrijker is dat de betrokkenen in het politieke discours, bijvoorbeeld vertegenwoordigende lichamen op alle niveaus, de verplichtingen uit art. 3.3 en 23.6 Ow serieus nemen en met de opstellers van omgevingsvisies en van de AMvB's over de praktische betekenis van de milieubeginselen in discussie gaan als dat inhoudelijk nodig is.

In het voorontwerp van de $\mathrm{Ow}$ was een algemene mogelijkheid tot het afwijken van in beginsel alle op grond van de $\mathrm{Ow}$ vastgestelde normen opgenomen voor zover dat Europeesrechtelijk mogelijk is. Deze 'positieve-

15. Zie bijv. H.F.M.W. van Rijswick, Een normatief kader voor het omgevingsrecht, in: Ch.W. Backes e.a., Naar een nieuw omgevingsrecht (Preadviezen voor de Vereniging voor Bouwrecht nr. 40), Den Haag: VBR 2012, p. 24 e.v.

16. Die met behulp van de voorhangprocedure worden vastgesteld, zie art. $23.5 \mathrm{Ow}$ evenredigheidsformule' heeft veel kritiek gekregen. ${ }^{17}$ Ook de Raad van State heeft destijds een dergelijke onbegrensde afwijkingsmogelijkheid als 'ongewenst' afgewezen. ${ }^{18}$ Gelukkig is een dergelijke bepaling in het uiteindelijke wetsvoorstel niet teruggekomen. Toch duikt dit spook in een andere gedaante weer op. De Raad voor de leefomgeving en infrastructuur (Rli) heeft in zijn advies 'Vernieuwing van omgevingsrecht' voorgesteld om een 'balansbepaling' in het Besluit kwaliteit leefomgeving $(\mathrm{Bkl})$ op te nemen die het mogelijk maakt om op decentraal niveau van bepaalde wettelijk vastgestelde normen te mogen afwijken als per saldo de omgevingskwaliteit verbetert. De bepaling zou bijvoorbeeld als volgt kunnen luiden:

'Het gemeentebestuur kan in concrete gevallen na een brede belangenweging afwijkende kwaliteit aanvaarden als het eindresultaat van het project, mede op basis van het advies van het kwaliteitsteam, per saldo leidt tot een gelijke of betere kwaliteit van de leefomgeving. ${ }^{\text {'19 }}$

Hoewel een dergelijke bepaling een minder ruime strekking zou krijgen dan de wettelijke formule van positieve evenredigheid gelden de daartegen naar voren gebrachte praktische $^{20}$ en principiële ${ }^{21}$ bezwaren ook voor deze clausule onverminderd. De wetgever heeft in de $\mathrm{Ow}$ en de daarop gebaseerde AMvB's vele mogelijkheden van afwijken van normstelling opgenomen. Die afwijkmogelijkheden zijn van tevoren bepaald en kunnen op verschillende niveaus 'aan- of uitgezet' worden. Een daarboven nog voorziene, niet nader gespecificeerde afwijkmogelijkheid is mijns inziens niet nodig, niet doelmatig en vanuit een democratisch oogpunt als 'carte blanche'bevoegdheid ook niet wenselijk. Het is aan de wetgever om, het liefst in de wet zelf, de buitengrenzen van afwijkmogelijkheden vast te leggen en zo de basiskleuren van het omgevingsschilderij te bepalen.

\subsection{Verlies aan herkenbaarheid door integratie}

In de thans geldende sectorale wetgeving is het desbetreffende aspect van het overheidsbeleid met krachtige kleuren uitgebeeld. De Wtw bevat een duidelijke blauwe doelstelling (art. 2.1), een heldere toedeling van taken en verantwoordelijkheden om die doelstellingen te bereiken (art. 3.1 e.v.), een uitgebreid, goed gestructureerd plannenstelsel (hoofdstuk 4), verplichtingen tot monitoring en verslaglegging (art. 2.12 e.v.), enzovoort. Daarmee

17. Zie bijv. B.J. Schueler, Of heeft u liever negatieve onevenredigheid? $M$ en R 2012, p. 241, H.D. Tolsma, Balanceren tussen economie en milieu in de Omgevingswet, NJB 2012, p. 2887 e.v. en Ch.W. Backes, Integraal en flexibel omgevingsrecht - droom of drogbeeld?, in: Ch.W. Backes e.a., Naar een nieuw omgevingsrecht (Preadviezen voor de Vereniging voor Bouwrecht nr. 40), Den Haag: VBR 2012, p. 46 e.v.

18. Raad van State, Voorlichting van 25 januari 2012, Kamerstukken II 2011/12, 33 118, nr. 3, bijlage IV, p. 19.

19. Rli, Vernieuwing Omgevingsrecht: maak de ambities waar, Den Haag 2015, p. 42 e.v.

20. Zie vooral A.G.A. Nijmeijer, Omgevingswet: maak de ambities waar, maar maak het niet ingewikkelder dan het al is, TO 2016, afl. 1/2, p. 2-3.

21. Zie Backes 2012, p. 46 e.v 
wordt een stevige grondslag gelegd voor een duidelijke positie van het waterbeleid in de politieke besluitvorming en beleidscycli. Ook de recent in werking getreden Wnb heeft een duidelijk afgebakende groene doelstelling (art. 1.10), duidelijke op het bereiken van die doelstelling gerichte planstelsels (art. 1.5 e.v.), monitorings- en verslagplichten (onder andere art. 1.9) en een heldere toewijzing van taken en verantwoordelijkheden (zie in het bijzonder art. 1.12). Dat draagt ertoe bij dat de bescherming en ontwikkeling van natuurwaarden in het politieke proces een duidelijke plaats kriigen. Een deel van deze blauw, grijs of groen ingekleurde instrumenten komt terug in de Ow. Zo moeten bijvoorbeeld, zoals wij al hebben gezien, omgevingswaarden ten behoeve van de waterveiligheid worden opgesteld. Ook kunnen specifieke taken en verantwoordelijkheden voor bepaalde deelaspecten van de zorg voor de fysieke leefomgeving op grond van art. 2.1 lid $3 \mathrm{Ow}$ nader worden uitgewerkt. Ook komen deels bijzondere verantwoordelijkheden al op wetsniveau terug. Zo zal bijvoorbeeld de voor het natuurbeleid cruciale verantwoordelijkheid van de provincies voor de opbouw en het functioneren van het Natura 2000-netwerk uit art. $1.12 \mathrm{Wnb}$ in art. 2.18 lid 1 Ow ook expliciet in de $\mathrm{Ow}$ worden verankerd. Dat geldt echter niet voor de planvorming, althans niet voor het vormgeven van een strategisch blauw, groen of grijs beleid. In de $\mathrm{Ow}$ zal bijvoorbeeld, indien de huidige consultatieversie van de Aanvullingswet natuur niet zou worden veranderd, niets staan over de noodzaak om strategische plannen voor het natuurbeleid of het waterbeleid vast te stellen of in omgevingsvisies een strategische visie voor het bereiken van bepaalde centrale blauwe of groene beleidsdoelstellingen uit te werken. Ook een monitorings- en verslagverplichting dienaangaande zal niet bestaan, respectievelijk niet gespecificeerd zijn. Het hoofdstuk monitoring bevat alleen een verplichting om te voorzien in monitoring van programma's en specifieke omgevingswaarden (art. $20.1 \mathrm{t} / \mathrm{m} \mathrm{20.5} \mathrm{Ow})$. Wel zal de Ow, als de consultatieversie Aanvullingswet natuur wordt gevolgd, een grondslag bevatten voor een bij $A M v B$ te scheppen verplichting om de toestand van bepaalde onderdelen van de natuur met monitoring te bewaken. Een volledig equivalent voor art. $2.12 \mathrm{Wtw}$ en art. 1.9 Wnb ontbreekt in de Ow. Daarmee neemt de herkenbaarheid van (bijvoorbeeld) blauwe en groene beleidsdoelstellingen en de agendering in de beleidscyclus af. Wetgevingstechnisch is dat een begrijpelijke consequentie van de beoogde soberheid van de Ow, maar dwingend is dit niet. De wetgever had voor de verschillende deelgebieden van het omgevingsbeleid kunnen voorzien in duidelijke verplichtingen om visies uit te werken en vervolgens periodiek te evalueren en te rapporteren in hoeverre de beleidsdoelstellingen op deze deelterreinen zijn bereikt of moeten worden bijgesteld. Dat zou niets afdoen aan het integrale karakter van de Ow. Het mogelijke tegenargument dat straks geen water-, milieu- en natuurbeleid meer bestaan, maar slechts nog integraal omgevingsbeleid, lijkt mij een volstrekte misvatting. Vóórdat een afstemming en integratie van verschillende onderdelen van het omgevingsbe- leid mogelijk zijn, moeten voor deze onderdelen strategische visies met bijbehorend voorstel tot operationalisering worden ontwikkeld. Dat volgt al uit de Europeesrechtelijke randvoorwaarden, maar deze zijn naar mijn mening ook zonder EU-eisen vereist om een hoogwaardig integraal leefomgevingsbeleid te kunnen voeren. Als men niet weet welke doelstellingen voor broeikasgassen, lucht- en waterkwaliteit en biodiversiteit men wil bereiken en wat elk van die doelstellingen vereist, kunnen ook geen gefundeerde afwegingen worden gemaakt. De aparte kleuren van het omgevingsrecht zouden in verschillende onderdelen en hoofdstukken van de Ow een duidelijkere, zelfstandigere en herkenbaardere plaats moeten krijgen voordat ze in één veelkleurig kunstwerk worden verwerkt. Dat geldt bijvoorbeeld voor het formuleren van strategische beleidsdoelen, voor het monitoren daarvan en het rapporteren daarover.

De herkenbaarheid, de agenderingsfunctie, de toedeling van duidelijke taakstellingen, de verantwoordelijkheden en de voor een bepaalde kleur voorziene plannings- en monitoringsverplichtingen garanderen echter niet dat veel van de desbetreffende kleur ook uiteindelijk in het omgevingsschilderij te zien is. Om in ons voorbeeld te blijven: het groen (of blauw) kan immers door blauw (of groen), grijs of rood worden overgeverfd en uiteindelijk uit het tafereel verdwijnen. Het grote voordeel van de Ow is dat gepoogd wordt te bevorderen dat met alle relevante sectorale doelstellingen en vraagstukken vroegtijdig in het afwegingsproces voor integrale plannen, programma's, algemene regels en individuele beschikkingen rekening wordt gehouden. Dat is, mits het lukt, een belangrijke vooruitgang en bevordert de totstandkoming van een mooi schilderij.

\section{Omgaan met verf - ook iets voor de wetgever?}

In paragraaf $2.3 \mathrm{kwam}$ al aan de orde dat de $\mathrm{Ow}$ (zo) weinig (mogelijk) materiële normstelling bevat. De wetgever heeft de keuze gemaakt om de materiële normstelling, waaronder beoordelingskaders voor aanvragen om individuele toestemmingsbesluiten, door te schuiven naar de AMvB's of zelfs op grond daarvan op te stellen instructieregels. Er zijn enkele wetgevingstechnische argumenten die hiervoor pleiten. De hoop is dat de wet daardoor robuuster wordt en minder gauw gewijzigd hoeft te worden. Er zijn echter ook wetgevingstechnische redenen die ertegen pleiten. Dat de Europeesrechtelijk in een samenhangende bepaling (bijvoorbeeld art. 6 Habitatrichtlijn) voorziene beoordelingscriteria in de Nederlandse wetgeving uit elkaar worden gerukt en deels in de wet en deels in een $\mathrm{AMvB}$ terechtkomen, verhoogt niet de helderheid, eenvoud en praktische toepasbaarheid. De verschuiving naar AMvB's en instructieregels betekent echter ook een verschuiving in de trias politica. Het parlement als medewetgever treedt terug en het bestuur, vooral het bestuur op nationaal niveau, 
wordt machtiger. Wie bevoegd is, welke omvang vergunningplichten hebben en wat daar de beoordelingskaders voor zijn, dat alles is straks ten minste deels niet meer in de wet te vinden en daar gaat dus het parlement niet meer over, maar het bestuur. ${ }^{22}$ Men kan zich afvragen of dergelijke beslissingen niet door het parlement zouden moeten worden genomen, althans mede, want de regering is samen met het parlement immers toch al medewetgever. Dat geldt ook, of wellicht nog meer, voor essentiële normen en langetermijnbeleidsdoelstellingen die de randvoorwaarden en de grove richting van het omgevingsbeleid voor de toekomst bepalen. Er is veel voor te zeggen dat het democratisch best gelegitimeerde orgaan het primaat zou moeten hebben bij het bepalen wat de streefcijfers zijn voor het reduceren van het grondstoffenverbruik of de CO2-uitstoot in 2030 en 2050 of het verminderen en stoppen van de teruggang van de biodiversiteit. Dat zijn immers beslissingen die het economisch en maatschappelijk systeem voor de komende decennia aanzienlijk zullen beïnvloeden. Het is dan ook begrijpelijk dat vanuit de Tweede Kamer de wens komt tot vaststelling van een Klimaatwet, waarin concrete reductiecijfers worden vastgelegd en in een plannings-, monitorings- en rapportagestelsel wordt voorzien. ${ }^{23}$ Ook met betrekking tot enkele andere principiële omgevingsbeleidsdoelstellingen, zoals het terugdringen van het grondstofgebruik, zou een soortgelijke 'inmenging' van het parlement op haar plaats zijn. Als de Ow zich beperkt tot een verfkist die een set verf in verschillende kleuren, penselen en kwasten bevat, maar bijna niets erover zegt hoe het omgevingsschilderij van de komende decennia er ongeveer uit zou moeten zien, wordt het parlement buiten spel gezet. Als het parlement dat niet (langer) accepteert, dan zullen naast de Ow andere wetten op het terrein van het omgevingsrecht ontstaan, die wel over de essentiële materiële beslissingen voor de toekomst gaan. De Klimaatwet is daar een goed voorbeeld van. Het is de vraag of het niet de voorkeur verdient dergelijke wetgeving te integreren in de Ow. Dan laat de Ow zien wat de kleurstelling van het omgevingsschilderij in grote trekken zal zijn. Dat lijkt mij een winst, niet alleen voor de effectiviteit van het beleid, maar ook voor de democratie. Grote transitieopgaven, zoals decarbonisatie en duurzaam grondstoffengebruik, kunnen niet vanuit één tak van het omgevingsrecht worden aangestuurd. Ze vereisen een integrale benadering van het omgevingsrecht. ${ }^{24}$ Als de juridische basis voor de aansturing van deze transitieprocessen in de Ow wordt neergelegd, krijgt deze majeure integratieoperatie een belangrijke rechtvaardiging en meerwaarde erbij, geheel overeenkomstig de

22. Zie ook de kritische opmerking van H.J.M. Havekes \& W.J. Wensink Omgevingswet waterproof?, TO 2013, afl. 2, p. 68 e.v.

23. Voorstel van wet van de leden Klaver en Samsom houdende een kader voor het ontwikkelen van beleid gericht op onomkeerbaar en stapsgewijs terugdringen van de Nederlandse emissies van broeikasgassen teneinde wereldwijde opwarming van de aarde en de verandering van het klimaat te beperken (Klimaatwet), Kamerstukken II 2015/16, 34 534, nrs. 1-3.

24. Dergelijke transitietaken raken naast het omgevingsrecht ook nog heel wat andere rechtsgebieden. wens die Michiels in zijn Utrechtse oratie heeft uitgesproken. 